\title{
CONTEMPORARY FIQH IN SINGAPORE: SOME OBSERVATIONS
}

\author{
Muhammad Haniff Hassan and Sharifah Thuraiya S.A. Alhabshi*
}

\begin{abstract}
This article offers the authors' observation on the current state and the development of contemporary Islamic jurisprudence (figh) in the Republic of Singapore. It begins by providing the theological basis for a figh that is contemporary and contextual to the changing time and place. The observation concludes that the state of a contemporary figh development is slow, if not stagnated. It then identifies the challenges that need to be overcome in order to change the current state of contemporary figh. Finally, the article presents some recommendations for overcoming the challenges and an improvement of the current state.
\end{abstract}

\section{Introduction}

The attempt to contemporise figh is not a recent phenomenon. It has always been a part of the fiqh evolution. The discourse to contemporise fiqh, has been a part of it. Over the last 100 years, Muslim scholars who were against the closure of the door of $i j t i h \bar{a} d^{1}$ during the period of taqli $d^{2}$ opined that fiqh must be contemporised to conform to the true spirit of $\operatorname{tashri}^{-}$(Islamic legislation). Also according to this view, figh should contribute to the development of the human intellect - and not to its stagnation and paralysis.

The constant need of Muslims to refer to figh in guiding their lives and offering solutions to their problems ensures that the discourse continues to date. This article hopes to contribute positively to the readers' appreciation of fiqh evolution in Singapore and how it can be improved to better serve the needs of Muslims in that country.

Before discussing those issues further, however, it must be clarified that the use of the terms 'contemporary fiqh' and 'traditional fiqh' is simply for purposes of categorisation devoid of any value judgement. The former refers to (1) a new fiqh viewpoint not found in classical tradition, as well as (2) a classical viewpoint

* Muhammad Haniff Hassan is Associate Research Fellow and a PhD candidate at the S. Rajaratnam School of International Studies (RSIS), Nanyang Technological University, Singapore. Sharifah Thuraiya S.A. Alhabshi is a Researcher at RSIS. The authors would like to express their gratitude to Zackaria Abdul Rahim for his kind technical assistance and input during the writing of this article. 
applied to a new contemporary context different from the original context when it was generated. The latter refers to fiqh as it is found in classical works.

Secondly, the discussion to contemporise fiqh is not a call to abandon traditional fiqh which has been a valuable intellectual treasure for Muslims. Rather, it is a call to resolve current issues by recognising that the present situation is different from the past while at the same time capitalising on past guidance and experience.

Thirdly, it must be pointed out that figh is a subset of the bigger issue of contemporary Islamic thought. Thus, the observations made in this article must be seen in that perspective. Although fiqh forms an important part of Islam and contemporary Islamic thought, it cannot be used to judge them. Nevertheless, the study is part of an important mosaic for understanding the broader picture of contemporary Islam and Islamic thought in Singapore.

\section{A Theological Basis of Contemporary Fiqh}

The need for contemporary fiqh stems from the fact that Islam is seen by Muslims as a comprehensive way of life $\mathrm{e}^{3}$ for mankind until the 'end of the world' and thus is able to offer solutions to human problems regardless of the time or age they live in. This can be seen from a verse in the Qur'ān which reads:

We have bestowed from on high upon thee, step by step, this divine writ, to make everything clear, and to provide guidance and grace and a glad tiding unto all who have surrendered themselves to God. (16:89)

Muslim scholars understand this verse in two ways: (1) all general principles needed to overcome problems in life can be found in the Qur'ān, and (2) the Qur'ān is the primary point of reference for overcoming problems in life.

At first glance, there appears to be a quandary: the content of the Qur'ān is fixed and unchanging but the universe that it seeks to guide is inherently ever-changing. This calls for a continual effort to perform ijtihād by inferring from the Qur'ān a new ruling for a new problem.

In performing ijtihād to solve new problems, Muslim scholars agreed that context (time and space) should always be taken into consideration in formulating fiqh rulings. It would be a serious mistake, according to the contemporary Egyptian scholar Yūsuf al-Qaraḍāwī (b. 1926), to issue fatwās based solely on opinions contained in the old fiqh books inherited from previous centuries without any effort to observe the changing conditions of today. ${ }^{4}$

In one of his works, the medieval Muslim jurist Ibn Qayyim al-Jawziyyah (d. 1350) dedicated in his book a "section on explaining changes in the fatwa according to changes in locations, times, conditions and customs". He then writes, "this section is very important and beneficial; whoever does not understand it, he 
cannot understand the shari ${ }^{\prime} a h$, will cause distress and hardship and will burden the servants of Allah with rulings that, in reality, do not comply with God's sharī 'ah". ${ }^{5}$

The Prophet himself, when dealing with problems and answering questions put forth by his companions, would take into account the relevant circumstances and situations surrounding the problem. This is why the Prophet had given different answers to the same question as seen in a hadìth narrated by Imām Abū Dāud (d. 889) from Abu Hurayrah (d. 681) who reported:

A man came to Allah's Messenger and raised a question about skin contact (al-mubāsharah) with his wife while he is fasting, then Allah allows this for him. Then came another man who asked the same thing, and Allah prevented and prohibited him from doing that. Why? Because the former was an old senile man, while the latter was young and gallant. ${ }^{6}$

It is well known that Imām al-Shāfi ' 1 (d. 820), the founder of the Shāfi ' $\overline{1}$ 'school' (madhhab) of Islamic jurisprudence, has two versions of opinion known as al-qadīm (early opinion) and al-jadìd (new/later opinion). The former was issued when he was in Iraq and the latter when he was in Egypt. The difference between the two versions is partly due to the different environments he was in. Muslim scholars have similar considerations when they formulated a general legal maxim: "custom/norm/ convention constitutes valid legal authority".

Efforts to contemporise fiqh cannot be regarded as bid 'ah (harmful innovation) because it is equivalent to figh al-wāqi - understanding realities in formulating figh ruling, a concept that had been used by scholars since the earliest time. Context consideration upon which contemporary figh is founded is also supported by the fact that the shari' ah was revealed to the Prophet Muhammad gradually or in stages.

A good example would be the gradual prohibition of alcohol. As consumption of alcohol was a deep-rooted custom of the Arabs at that time, it was impractical to command total abstinence immediately. ${ }^{8}$ Therefore, the first revelation on alcohol consumption was merely a disapproval of its negative effects, i.e. drunkenness. ${ }^{9}$ After some time, Muslims were prohibited from performing the obligatory prayers in a state of drunkenness. ${ }^{10}$ The consequence of this prohibition is the reduction of time and opportunity to drink alcohol due to the time of prayers. It was only 15 years after the first revelation which banned alcohol completely. ${ }^{11}$ Closer study of the shari 'ah would also reveal the existence of naskh (abrogation), which supports the idea of changing a ruling due to a changing context as demonstrated in the aforementioned prohibition of alcohol.

The core principle of contextual thought in Islam is also enshrined in the verse of the Qur'ān (2:286) which reads, "God does not burden any human being with more than he is well able to bear; in his favour shall be whatever good he does, and against him whatever evil he does." This implies that Islam acknowledges the limitation a Muslim has when practising his/her own religion; and that man 
is not perfect in his actions. Hence, a Muslim is obligated to only do the best he can within the constraints. Transgression of the limitation and constraint beyond rational thinking are thus forbidden, and are against the principles of justice - one of the main Attributes of Allah.

Contemporary figh could also be supported from the existence of $r u k h s a h^{12}$ in the shari' ah. Rukhsah is legal exemption from the original rule ('azimah) determined by the shari' 'ah upon a Muslim due to a difficulty, harm or other recognised impediments. Rukhsah is a system of 'checks and balances' to ensure that the sharī'ah can be practised easily and comfortably. A verse in the Qur'ān reads: "And, behold, with every hardship comes ease" (94:5). Here, the prohibition of carrion can be taken as an example of the application of rukhsah. Even though it is forbidden (harām) to consume meat from an animal that has not been slaughtered in line with Islamic principles or which has perished on its own, a person who is stranded in the middle of a desert without any food is permitted to consume carrion in order to survive. Rukhsah allows a change of the ruling, in such situations, from that of prohibition to that of permissibility or even one that is obligatory. In essence, rukhsah is permitted with the objective of providing flexibility to Muslims who face changes in the context they live in.

Finally, there are established fiqh maxims in Muslim legal tradition. These maxims, when studied in depth, depict the flexible character of Islam in encountering different situations and realities. Some examples of the maxims are: ${ }^{13}$

- hardship begets facility (al-mashaqqah tajlib al-taysīr);

- necessity makes the unlawful lawful (al-darūrāt tubīh al-mahz̧urāt);

- prioritising a greater benefit over a lesser one (taqdìm mașlahah kabìrah 'alā mașlahah șaghīrah);

- a greater harm is eliminated by means of a lesser harm (dar ' mașlahah kabìrah muqaddam 'alā dar' mașlahah șaghīrah);

- a lesser harm is tolerated in order to attain a larger benefit (tughtafar mafsadah șaghīrah min ajl mașlahah kabīrah).

Based on the above arguments, a contemporary fiqh is thus a religious necessity because,

- new problems will continue to arise from new contexts, requiring new solutions;

- without contemporary fiqh, the comprehensiveness of Islam and the mercy it brings to the entire universe will not be realised;

- not adapting figh to current realities, hardship and injustice are likely to occur; 
- without harmonising figh with current context, people will risk a life solution that is not in compliance with the sharì $a h$, without realising it.

Al-Qaraḍāwī regards the issuance of fatwās without a detailed and correct understanding of the contemporary world as dangerous. He likens it to "a medical doctor who would prescribe an expensive treatment for his patient before conducting a thorough analysis, prior check-up, and careful diagnosis". ${ }^{14}$

\section{Contemporary Figh in the Context of the Muslim Community in Singapore}

The objective of this section of the article is to present key features of the Muslim community in the Republic of Singapore, relevant to the issue at hand.

The Singapore Muslim community lives in a multi-cultural and cosmopolitan society. They form a minority, which is only about 13 per cent of the total population of about 5 million people (citizens as well as non-citizens) and live in an advanced country, one of the original 'Four Asian Tigers' which in the meantime has achieved the status of a 'developed economy'. The community does not hold dominant political power, unlike its Muslim/Malay brethren in Malaysia, Indonesia, and Brunei. This does not imply, however, that the Muslim community in Singapore is left with no voice in the political domain. There are currently eleven Malay-Muslim Members of Parliament and one full Minister in the ruling People's Action Party (PAP). A portfolio to look after Muslim affairs has been traditionally allocated to ensure Muslim representation in cabinet.

There is a clear sign of increased awareness on contemporary fiqh among the Muslims in Singapore today particularly in the areas of finance and politics. Trade development and the country's economic interests have helped develop Islamic banking and the finance industry. This in turn has led many professionals as well as members of society to acquire knowledge relevant to the industry. The 9/11 attacks that catapulted the issue of Muslim terrorism and the threat of $\mathrm{J}^{15}$ ideology have also increased attention to issues such as Islam and politics, jihād as well as relations between Muslims and non-Muslims. However, the writers of these lines observe that the state of development of contemporary fiqh here is rather slow, if not stagnated. There is a serious lack of a lively discourse in the public sphere on contemporary fiqh.

Despite lively and dynamic da'wah (propagation of Islam) activities, as can be seen by the many advertisements in Berita Harian, a local Malay-language newspaper, fiqh education for common and ordinary folks has been largely confined to the traditional fard al-'ayn (personal religious obligations). Any new issue is 
often addressed from the perspective of an established position or lens found in traditional and classical works.

The academic and intellectual activities involving the community's intelligentsia on contemporary fiqh is stale and unproductive. One important indicator in this aspect is the absence of any serious research work or publication related to new issues of figh concerning the local community or Muslims at large. Books written by internationally renowned Muslim scholars such as Țāriq Ramaḍān and Yūsuf al-Qaraḍāwī, however, are freely available at local Muslim bookstores.

There is a lack of some sort of platform in the shape of institutions or civil society that is dedicated to or gives sufficient attention to develop and apply contemporary fiqh within the context of the Singapore Muslim community. To date, the only important activities, means, and discourse which contribute consistently to the development and application of contemporary fiqh are those by the Islamic Religious Council of Singapore (MUIS, Majlis Ugama Islam Singapura) through the issuance of fatwās by its Fatwa Committee and other units. ${ }^{16}$ This can be seen from a series of fatwās in recent years which address the shari ${ }^{-} a h$-ruling of joint tenancy contracts of a property, ${ }^{17}$ the nomination of the Central Provident Fund $(\mathrm{CPF}),{ }^{18}$ the automatic inclusion of a Muslim as a donor for organ transplantation under the Human Organ Transplant Act, unless he explicitly declared otherwise, ${ }^{19}$ advance health care directive, ${ }^{20}$ the use of stem cells from embryos below 14 days for research purposes,${ }^{21}$ and the use of ethanol as a solvent, ${ }^{22}$ as well as the series of international conferences on waqf (inalienable religious endowment) development ${ }^{23}$ and haläl certification. ${ }^{24}$

Admittedly, there are other channels such as private religious institutions, Muslim organisations and individuals. The Singapore Islamic Scholars and Religious Teachers Association (PERGAS, Persatuan Ulama dan Guru-Guru Agama Islam Singapura), for example, held the Convention of 'Ulamā' in 2003. This subsequently catalysed the publication of a book in 2004 entitled Moderation in Islam in the Context of the Muslim Community in Singapore. ${ }^{25}$ The book seeks to guide the Muslim community towards a moderate and contextual practice of Islam in Singapore in response to the discovery of the JI terror plot in the country and the $9 / 11$ attacks that worried the world. In 2008, PERGAS then published in collaboration with a local publisher a translated work of two scholars on the issue of fiqh for Muslim minority living in a non-Muslim majority country like Singapore ${ }^{26}$ However, these are more of an exception than the rule, if one were to look at its activities over the past decade prior to $9 / 11$. Having said that, however, its contribution in $d a^{\prime} w a h$ and safeguarding the traditional figh through its educational programme must be highly recognised and complimented.

There are Muslim-run think-tank organisations in Singapore which study issues pertaining to Islam and Muslims. Their limited contributions, however, will be 
touched upon in the subsequent relevant paragraphs. There are several important factors which contribute to the stale state of contemporary fiqh development in Singapore. The first is the absence of Islamic institutions of higher learning in Singapore or an institute of higher learning offering Islamic studies courses. To date, there does not exist any department of Islamic studies in the institutions of higher learning in Singapore. The only department available is the Department of Malay Studies which operates within the Faculty of Arts at the National University of Singapore (NUS). There are six full-time formal religious schools offering traditional studies and are based on the national academic curriculum from primary to upper secondary levels with the objective of producing the religious elites of the local Muslim community. At the post-secondary level, there is only one private institution - Institut Al-Zuhri - which is offering an Islamic studies programme of its own at diploma level which has received recognition by many private Islamic universities and colleges in Malaysia for continuation at degree level. ${ }^{27}$ In addition, there are a few Islamic studies programmes at diploma, degree and postgraduate level from foreign universities in Malaysia and Indonesia offered here in collaboration with local Muslim organisations. The programmes are conducted largely by academics of the foreign institutions with a minimum role played by local Muslim scholars. Despite the existence of these external programmes, graduates of local Islamic schools are largely furthering their Islamic studies at institutions of higher learning in foreign countries. It can be argued that the lack of a full-fledged local Islamic institution of higher learning or, at least, a faculty of Islamic studies has a significant effect on the overall traditional figh orientation of the community and has impaired the development of a contemporary one, such that:

- Islamic studies graduates do not have a platform to hone their knowledge in an academic environment. Most of them end up teaching fard al- 'ayn in mosques or Muslim organisations.

- There is a superficiality to the academic activities among female religious teachers (asätidhah) and the Islamic community, as a result of lack of proper academic environment. This is also evident in the lack of quality published research materials on Islamic issues, i.e. in the form of newspaper articles, magazines, books, etc. It is also the reason why many contemporary issues are sometimes missed out or not sufficiently discussed. This affects the pattern and degree of public awareness and appreciation of a contemporary figh.

- There are limited career incentives to produce experts in various fields of Islamic studies. This has resulted in the lack of experts specialising in the field of Islamic jurisprudence. In Singapore today, there are hundreds of graduates of Islamic studies, but there are fewer than five PhD holders. 
The second factor is the absence of research and think-tank institutions that contribute to and engage in contemporary figh discourse in an effective manner. The role of research and think-tank institutions, in the authors' opinion, are equally important in the development of contemporary fiqh. They complement the role played by institutions of higher learning. Indeed, research and think-tank institutions are recognised together with universities as part of an academic community.

Examples of important research and think-tank institutions in neighbouring Malaysia which have contributed to contemporary Islamic thought are the International Institute of Islamic Thought and Civilization (ISTAC) whose founderdirector was Professor Syed Muhammad Naquib al-Attas, the Institute of Islamic Understanding Malaysia (IKIM) ${ }^{28}$ and the International Institute of Islamic Thought, Malaysia (IIIT) - not to mention IAIS Malaysia, the publisher of this journal. ${ }^{29}$ Closely associated with Malaysia's political and religious establishment, IKIM in particular plays an important role in shaping the religious policies of the Malaysian government and the understanding of Islam among Malaysians through research work which is relevant to contemporary issues such as bio-ethics, ${ }^{30}$ Islamic management and governance, ${ }^{31}$ food technology, ${ }^{32}$ cloning, ${ }^{33}$ as well as contemporary Islamic law, ${ }^{34}$ and environment. ${ }^{35}$ It also operates its own popular radio station to reach out to ordinary people and promote a contemporary Malaysian Islamic lifestyle. ${ }^{36}$ IAIS Malaysia, in turn, as an independent think-tank might even establish itself as the one-stop reference point when addressing contemporary issues affecting Muslims in Southeast Asia and on the international sphere. IIIT had once played an important role of popularising the idea of 'islamisation of knowledge' that would reshape the Muslim mind to overcome contemporary new challenges. Although the idea of 'islamisation of knowledge' has lost much of its currency today, credit should still be given for its contribution to the promotion of a critical review of traditional Islamic thought in the contemporary setting.

Indeed, in Singapore itself there are several research institutes involved either directly or indirectly in the study of Islam and contemporary issues in Singapore, such as the Centre for Contemporary Islamic Studies (CCIS) and Centre for Research and Islamic Affairs (RIMA). In addition, several other research institutes have special programmes pertaining to Islamic thought. The S. Rajaratnam School of International Studies (RSIS), for example, undertakes a Contemporary Islam programme. Alas, the research agenda of RSIS is mostly determined by the 'strategic needs' of Singapore and its government. Therefore the contribution of these institutions to the development of a contemporary fiq $h$ in Singapore is arguably insignificant. This is primarily due to the fact that the work done there consists mainly in social research, not in fiqh.

This can be discerned clearly from RIMA's publications, although the institute's objective is to undertake research on Islam and Malay/Muslim society and provide 
a more focused approach in the study of Islamic and Malay issues in Singapore. ${ }^{37}$ CCIS stated its objectives as "to conduct research, organise seminars, lectures, conferences and meetings on contemporary Islamic issues and matters concerning the Muslim community; to publish, sell and distribute printed and multi-media materials on contemporary matters; to organise, participate and assist in educational activities" ${ }^{38}$ This would include figh issues. However, its real activities centre around intercivilisational dialogue, ${ }^{39}$ public talks, ${ }^{40}$ and regular contributions of op-ed articles ${ }^{41}$ to local newspapers by its board members. Its talks and articles cover a wide range of topics.

This lack of intellectual vibrancy and focus means that the Muslim community at the grassroots level is not regularly exposed to religious discourse that handles contemporary issues with contemporary solutions. Consequently, this affects the community's level of understanding and appreciation of fiqh for the contemporary period. The contributions of these institutions are essential because they complement the fatwa institutions that tend to be reactive to questions posed to them. Unlike the fatw $\bar{a}$ institutions, academic and research institutions are free to address new issues that emerge or speculate on future issues without waiting for questions to be posed. In fact, all good academic and research institutions are expected to 'think ahead' of challenges and be pro-active.

The third factor is the lack of discourse on Islam and contemporary issues in the media. In view of the important role played by media today in shaping the minds of the community and the understanding of contemporary figh, the development of contemporary figh would be enhanced if there were strong media backing. The mainstream media's involvement in promoting an Islamic discourse on contemporary issues and fiqh within the Singapore context is significantly limited due to the secular policy adopted by the authorities. This is unlike the media in two of the neighbouring countries, i.e. Malaysia and Indonesia. One can hardly find a single programme in the media, including Malay-language television in Singapore, which touches on Islam and contemporary issues on a regular basis. Suria, the Malay-language television channel, has programmes such as Detik, Bicara, and Akhir Kata which sometimes discuss issues related to Muslims and Islam, but the majority of them are general topics. The situation is aggravated further by the lack of publications by local Muslim scholars on figh in contemporary times. Consequently, there is a lack of the promotion, debate, and discussion that would usually follow. There is also a very limited number of articles written on Islam and current issues in the local Malay-language newspapers.

These factors thus lead to a superficial and shallow awareness and appreciation of a contemporary fiqh among Singapore's Muslim community. Often, the result of this is a gap between issued fatwās and public comprehension. The existence of this gap is among the reasons for the polemics and rejection of certain fatwās issued 
by the Fatwa Committee due to incomprehensible juristic arguments. However, not only do these polemics drain valuable resources which are best used for other purposes, they also lead to tension among the community's stakeholders. A good understanding and appreciation of a contemporary fatwās would help the Muslim community toward a better understanding of fatwās. Even if a fatwa is contentious in nature, like many of the contemporary issues due to the ambiguity of the relevant religious texts, it would be much easier to manage the disagreement in order to avoid tensions and disreputable debates.

\section{Challenges of Contemporary Figh Development in Singapore}

It is contended that the improvement of the current development state of contemporary figh in Singapore faces some challenges which need to be overcome if the efforts are to succeed in the long run.

The first challenge is the dire need to uplift the Muslim community's level of knowledge in traditional as well as contemporary fiqh. It is observed that, generally, the Muslim community's grasp and appreciation of figh centres around the topics of ritual cleanliness (tahārah) and worship ( 'ibādah) - topics that are covered by most religious classes conducted in mosques and Muslim organisations. One can find only a few classes that teach other areas of figh as extensively as those of tahärah and 'ibādah. The other areas of fiqh include munākahàt (marriage), mu' āmalāt (trade and business activities), jināyāt (criminal law), and jihād (spiritual as well as armed struggle). A community's discourse on fiqh that is limited to tahārah and 'ibādah is a gauge of its (poor) level of appreciation of contemporary fiqh because contemporary fiqh often deals with unprecedented new problems, which occur outside the domains of tahārah and 'ibādah. The issues in the domains of tahārah and 'ibädah are mostly fixed and less affected by the changing times and contexts. Moreover, the issues in both domains have long been discussed and deliberated by the early scholars through speculative hypothetical cases. It is acknowledged that there are a few Muslim organisations, in addition to the full-time Islamic schools, offering Islamic Studies programmes that include a wide range of fiqh studies. However, they are largely taught from the traditional fiqh viewpoint instead of the contemporary one. This is so even at the full-time madrasah. Furthermore, their reach to the community is limited due to the limited number of intake and availability of the programme.

The second challenge to the development of contemporary fiqh is to educate the Muslim community to understand and practise figh through the understanding of its legal arguments, instead of the final ruling only. The aim of this endeavour is not to make them all religious teachers or qualified fatwa $\bar{a}$ issuers, but to make them understand the bases of their practices and understanding. This would accustom 
their minds to the underlying principles of fiqh and the related thought processes, which would facilitate an easier and better understanding of new fig $h$ that addresses contemporary issues and to a certain extent help them to solve contemporary problems that they face in their day-to-day lives, in line with the verses in the Qur'ān which read:

And never concern thyself with anything of which thou hast no knowledge. (17:36) and

Say [O Prophet]: 'This is my way: Resting upon conscious insight accessible to reason, I am calling [you all] unto God - I and they who follow me.' And [say:] 'Limitless is God in His glory; and I am not one of those who ascribe divinity to aught beside Him.' (12:108)

It is also hoped that such a step would revitalise the excellent intellectual culture of early Muslims among the Muslim community in Singapore in relation to their religious understanding and practices. Cultivating the understanding and practice of figh based on its legal arguments would be useful to prepare a mind that is receptive to contemporary fiqh and would consequently contribute to the overall environment where contemporary figh could flourish. This is because, in most circumstances, contemporary fiqh deals with how to apply shari 'ah legal proof in dealing with new and contemporary issues. If the minds of the Muslims are familiar with and receptive to the legal proofs and thought process, it would be easy for them to perceive various issues in the contemporary sense and solve their contemporary personal problems without neglecting sharī'ah principles.

In line with the need to contemporise fiqh, there is also the need to develop fiqh that suits, where possible and necessary, the unique character of the Singapore context, especially those related to specific problems faced by Muslims as a minority in Singapore. This is the third challenge to overcome. Moreover, fiqh that is unique to Singapore is itself a challenge because figh known by the Muslims today is generally less concerned with the context of Muslims as a Muslim minority in non-Muslim countries. This is due to the fact that the traditional fiqh that is inherited and studied today was influenced by and developed in a predominantly Muslim environment - politically, socially and economically.

There are already initial attempts towards this, as demonstrated by the publication of Moderation in Islam in the Context of the Muslim Community in Singapore by PERGAS. This was followed by the publication of Risalah by MUIS, which prescribes the attribute of an excellent Singaporean Muslim community. ${ }^{42}$ However, more of such efforts are needed in the form of local original publications or, at least, translations of relevant works for the Muslim community's reading and study.

The type of ideas posited by Tariq Ramadan in his books To Be a European Muslim ${ }^{43}$ and Western Muslims and the Future of Islam, ${ }^{44}$ as well as recent works on fiqh 
al-aqalliyāt (fiqh for Muslim minorities) discussed by some other eminent scholars like Ṭāhā Jābir al- 'Alwānī (b. 1935) ${ }^{45}$ and the earlier-mentioned al-Qaraḍāwīi, ${ }^{46}$ should be explored and developed further in line with the Singapore context.

Inevitably, producing a pool of experts in various aspects of figh and its related sciences is another challenge to overcome if contemporary figh is to flourish. Human capital is the most important asset, especially in issues related to knowledge. Thus, the existence of shari 'ah experts particularly in the field of contemporary figh, is key in order to improve the current state and overcome the challenges described in this article. Their existence is not only critical for the development of contemporary fiqh but more importantly it is to ensure that the development is based on true principles laid down by the Qur'ān and the Sunnah and without total disregard of the existing rich intellectual heritage. This is to protect the Muslim community from falling into a situation described by the Prophet in a hadith which reads:

Allah does not take away the knowledge, by taking it away from (the hearts of) the people, but takes it away by the death of the religious learned men till when none of the (religious learned men) remains, people will take as their leaders ignorant persons who when consulted will give their verdict without knowledge. So they will go astray and will lead the people astray. ${ }^{47}$

The Prophet also said in another hadìth: "Anyone who gives a religious opinion without knowledge will bear the sin of issuing it."

\section{Conclusions and Recommendations}

In view of the current state and challenges facing the development of contemporary fiqh in Singapore, the authors would like to recommend some broad steps for improvement:

- There is a serious need to revaluate and revamp the learning of fiqh among Muslims in Singapore in a holistic fashion across all levels of society. The end result is to have comprehensive programmes teaching figh which would not only reach out to different segments of the community but also cover most aspects of figh beyond the domains of 'ibādah and tahärah. This must also include new learning and instructional methods. There have been a number of measures and changes made by individual teachers and institutions to introduce new methods of learning, such as the 'Kids and Teens Alive' programmes initiated by MUIS. However, this initiative has not covered all levels of the community and all aspects of fiqh. Thus, much more needs to be done to transform the culture of learning figh. 
- The learning of contemporary fiq $h$ must be popularised within the society. It can be an extension of traditional figh, i.e. by providing a contemporary figh course which uses works that cover contemporary fatwās, such as al-Qaraḍāwì's book al-Fatāwā al-mu 'așirah ${ }^{49}$ (the original Arabic or translated versions), and by including it in the curriculum of the six full-time religious schools throughout the island republic.

- There must be a serious effort to cultivate a high appreciation of traditional sciences related to fiqh, such as the qur'ānic sciences ('ulüm al-qur'ān), hadìth sciences ('ulüm al-hadìth), the principles of fiqh (ușül al-fiqh) and fiqh maxims (qawa id fiqhiyyah). These sciences are fundamental in helping the community to appreciate better a figh which is rooted to its legal argument and to use them as tools for decision-making and problem-solving, as well as to be able to comprehend contemporary fatwās.

- The establishment of local Islamic institutions of higher learning would catalyse many academic activities as spin-offs that would contribute to the transformation of a new learning culture of $f i q h$ among the Muslim community. Active efforts to elevate the academic profiles of female religious teachers by enabling them to obtain MAs or PhDs through various incentives and support need to be initiated in the hope of producing more experts in various aspects of figh. Admittedly, MUIS has taken steps with its MUIS scholarship award..$^{50}$ However, the impact on the state of contemporary figh remains limited due to its infancy stage. The Prophet Muhammad's Birthday Memorial Scholarship Fund Board (LBKM) ${ }^{51}$ has also disbursed annual bursary awards for postgraduate studies, although on a much smaller scale than MUIS. ${ }^{52}$ It is thus hoped that more can be allocated for this purpose - to contribute to the uplifting of the state of contemporary figh and to a greater extent also contemporary Islam in Singapore.

Today, the establishment of Islamic institutions of higher learning does not necessarily need to begin from scratch. There has been a trend among institutions of higher learning to conduct, for example, twinning programmes and franchises, as carried out by private institutions of higher learning. By using the same system, an Islamic institute of higher learning can be realised.

There are already ongoing initiatives. Institut Al-Zuhri, for example, offers a full-time diploma in Islamic studies on its own. Muhammadiyah Islamic College offers a few degree programmes related to Islamic studies in collaboration with a university in Indonesia. ${ }^{53}$ PERGAS offers diploma and degree programmes in Islamic studies that are conferred by two Malaysian institutes. ${ }^{54}$ Lastly, MUIS Academy offers a Master's programme from an Indonesian university. ${ }^{55}$ However, except for the above-mentioned diploma, all these programmes are offered on a part-time basis and none of them are 
fully conducted by locals. Thus, the expected spin-off from these programmes to promote contemporary figh is not realised.

- Activities generated by research and think-tank institutes as another means to promote a contemporary fiqh must be promoted. The primary role of these activities is to generate new ideas in figh pro-actively to address current or future issues/challenges that require solutions from figh. These activities will function as the community's brain in matters of $f i q h$, and complement the role of the Fatwa Committee in Singapore in their proactiveness.

Concerns and recommendations discussed in this article are coincidental with parts of MUIS's third three-year strategic plan presented in the MUIS Workplan Seminar on 10 April $2010 .{ }^{56}$ In its plan to develop religious content that is relevant to the Singapore context, MUIS aims at encouraging deep and critical thinking among students when inferring knowledge to current issues, as well as introducing new areas of knowledge. ${ }^{57}$ The strategy also seeks to review the current curriculum of the full-time madrasah, as well as general public education. ${ }^{58}$

However, the development of contemporary fiqh in Singapore must not over-rely on MUIS. It is critical to have the active participation and extensive contribution of other stakeholders in the Muslim community in Singapore such as Muslim organisations, and PERGAS in particular which is the sole umbrella body for local Muslim scholars. In this regard, MUIS should include as part of its strategy an implementation to persuade other stakeholders to contribute to the same objective of developing a contemporary unique Singapore $f i q h$ in their own ways and allocate incentives as encouragement.

Finally, the authors would like to remind themselves that in the enthusiasm to contemporise fiqh to meet the contemporary needs and challenges, one must be aware that despite its principles of flexibility (murūnah) that are adaptable to any situation, Islam also consists of fundamentals (thawäbit) that are unchangeable despite the changing contexts. Although Islam must not be practised and presented in a rigid manner, the need to be conscientious to protect the fundamentals from being diluted by the changing times must be emphasised..$^{59}$ Therefore, one should not forget the virtues of piety and God-consciousness in the endeavour for a more contemporaneous fiqh.

\section{Notes}

1. Ijtihād refers to independent legal reasoning through interpretation of the legal sources, the Qur'ān and the Sunnah. The opposite of ijtihäd is taqlïd, which means imitating the opinion of a scholar or mere blind following of a madhhab (a legal 'school' of Islam); see Mohammad Hashim Kamali, Shari'ah Law: An Introduction (Oxford: Oneworld, 2008), 36 and 162-3.

2. Ibid. 
3. See Qur'ān 3:19, 85 and 5:3.

4. Yūsuf al-Qaraḍāwī, Al-Fatwā bayn al-indibat wa-'l-tașayyub, available online at http:// www.qaradawi.net/site/topics/article.asp?cu_no $=2 \&$ item_no $=2913 \&$ version $=1 \&$ template id=24\&parent_id=1 (accessed on 5 July 2006).

5. Ibn Qayyim al-Jawziyyah, I' lām al-muwaqqi 'ìn 'an rabb al- 'ālamīn (Beirut: Dār al-Kutub al- 'Ilmiyyah, 1991), 3:12.

6. Ibid.

7. See Jalāl al-Dīn al-Suyūṭị, Al-Ashbāh wa- 'l-nazā 'ir (Beirut: Dār al-Kutub al- 'Ilmiyyah, 1979), 89.

8. Yūsuf al-Qaraḍāwī, Al-Khașā' 'ị al- 'āmmah li-'l-islām (Cairo: Maktabah Wahbah, 1977), 170-3.

9. See Qur'ān 16: 68 and 2:219.

10. Ibid., 4:43.

11. Ibid., 5:90.

12. Ibrāhīm b. Mūsā al-Shāțibī, al-Muwāfaqāt (Damascus: Dār al-Fikr, 2000), 1:210.

13. It is important that these maxims are not to be understood based solely on their literal meanings. Since it is not the objective of this article to discuss these maxims, please see the following references for detailed elaboration: al-Suyūțî, Al-Ashbāh, and Yūsuf al-Qaraḍāwī, Fì fiqh awlawiyyāt: Dirāsah jadìdah fi daw' al-qur'ān wa-'l-sunnah (Cairo: Maktabah Wahbah, 1995).

14. Yūsuf al-Qaraḍāwī, Al-Thaqāfah al- 'arabiyyah al-islāmiyyah bain al-așālah wa-'l-mu 'āṣirah, Malay transl. Ahmad Nuryadi Asmawi (Batu Caves, Selangor [Malaysia]: Thinker's Library, 1996), 97-8.

15. JI or Jemaah Islamiah (al-Jamā 'ah al-Islämiyyah, lit. 'Islamic Congregation') is a Southeast Asian militant organisation aiming at the establishment of a regional 'Islamic caliphate'.

16. See section 30-33, Administration of Muslim Law Act (Singapore).

17. Fatwa $\bar{a}$ by MUIS Fatwa Committee, dated 3 April 2008.

18. Ibid., dated 3 August 2010.

19. Ibid., dated 17 July 2007.

20. Ibid., dated 20 September 1994.

21. Ibid., dated 22 November 2001.

22. Ibid., dated 7 August 2008.

23. Singapore International Waqf Conference, held by MUIS on 2-7 March 2007.

24. Haläl Seminar, held by MUIS on 21 August 2009.

25. See PERGAS, Moderation in Islam in the Context of the Muslim Community in Singapore (Singapore: PERGAS, 2004).

26. Muhammad Haniff Hassan (transl.), Fiqh minoriti muslim: Dari perspektif dua ulama kontemporari (Singapore: PERGAS and Pustaka Nasional, 2008).

27. See the introduction on Institut Al-Zuhri, its programmes and recognition received, available online at http://zuhri.com.sg/index.php?option=com_frontpage\&Itemid=1 (accessed on 29 November 2010).

28. See the introduction to IKIM, available online at http://www.ikim.gov.my/v5/index. php? $1 \mathrm{~g}=2 \&$ opt $=$ com_info\&grp=5\&men=40\&key=1009 (accessed on 10 November 2010$)$.

29. See the introduction to IIIT, available online at http://www.iiit.org/AboutUs/AboutIIIT/tabid/66/ Default.aspx (accessed on 10 November 2010).

30. See Abu Bakar Abdul Majeed (ed.), Bioethics: Ethics in the Biotechnology Century (Kuala Lumpur: IKIM, 2002).

31. See Nik Mustapha Nik Hassan and Sh. Mohd Saifudeen Sh. Mohd Salleh, Corporate Governance From the Islamic Perspective (Kuala Lumpur: IKIM, 2002); see also Mokhtar Abdullah et al. (ed.), Essays on Islamic Management and Organisational Measurement (Kuala Lumpur: IKIM, 2003).

32. See Sh. Mohd Saifuddeen Sh. Mohd Salleh (ed.), Food and Technological Progress (Kuala Lumpur: IKIM, 2006).

33. See Majdah Zawawi, Human Cloning: A Comparative Study of the Legal and Ethical Aspects of Reproductive Human Cloning (Kuala Lumpur: IKIM, 2001). 
34. See Zainal Abidin Abd. Rahman, Islamic Law in the Contemporary Law (Kuala Lumpur: IKIM, 2003).

35. Abu Bakar Yang and Abu Bakar Abd. Majeed (eds), Pengurusan bijak alam sekitar (Kuala Lumpur: IKIM, 2000); see also the information on IKIM's Centre for Science and Environment Studies, available online at http://www.ikim.gov.my/v5/index.php?lg=2\&opt=com info\&grp $=5 \&$ men $=41 \&$ key $=1019$ (accessed on 11 November 2010$)$.

36. See the information available online at http://www.ikim.gov.my/v5/index.php?lg=2\&opt=com info\&grp $=5 \&$ men $=43 \&$ key $=1762$ (accessed on 10 November 2010$)$.

37. See the list of the RIMA Occasional Article Series, available online at http://www.rima.sg/subindex. asp?id=A006_10, and the list of books published by RIMA, available at http://www.rima.sg/ subindex.asp?id=A007_09 (both accessed on 11 November 2010).

38. See the introduction to CCIS, available online at http://www.ccis.org.sg/ccis-web/web/index.asp (accessed on 29 November 2010).

39. See CCIS, "Intercivilization Dialogue”, available online at http://www.ccis.org.sg/ ccis-web/web/T_sub_template.asp?mhtyp=Interfaith\%20Dialogue\&ptype=Interfaith $\% 20$ Dialogue\&sno $=309 \&$ art_id $=$ ART00031-2003\&pn $=1 \&$ fout $=5 \& \mathrm{tCa}=\mathrm{S}($ accessed on 29 November 2010).

40. See CCIS, "List of Previous Talks", available online at http://www.ccis.org.sg/ccis-web/ web/T_Template 2 .asp? mhtyp $=$ List $\% 20$ of $\% 20$ Previous $\% 20$ Talks \&ptype $=$ March $\% 20$ $2004 \&$ sno $=357 \&$ art_id=ART00078-2003\&pn $=1 \&$ fout $=1 \&$ tCat $=$ S (accessed on 29 November 2010).

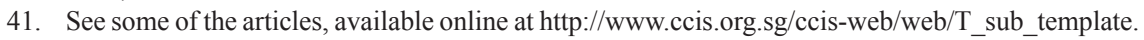
asp? $\mathrm{mhtyp}=$ Press\%20Releases\&ptype $=$ Press\%20Releases\&sno=308\&art_id=ART00030$2003 \& \mathrm{pn}=1 \&$ fout $=4 \& \mathrm{tCat}=\mathrm{S}$ (accessed on 29 November 2010 ).

42. Office of the Mufti, "Risalah for Building a Singapore Community of Excellence" (Singapore: MUIS, 2006, 2nd ed.), available online at http:/www.muis.gov.sg/cms/uploadedFiles/MuisGovSG/ Downloads/Risalah-eng-lr.pdf (accessed on 29 November 2010).

43. See Tariq Ramadan, To Be a European Muslim (London: Islamic Foundation, 1999).

44. See idem, Western Muslims and the Future of Islam (Oxford: Oxford University Press, 2004).

45. See Taha Jabir Al-Alwani, "Towards a Fiqh for Minorities: Some Basic Reflection", Occasional Article Series 10 (Herndon VA: International Institute of Islamic Thought, 2003).

46. See Yūsuf al-Qaraḍāwī, Fiqh al-aqalliyyāt al-muslimah: Hayāt al-muslimīn wasaț al-mujtama 'āt al-ukhrā (Cairo: Dār al-Shurūq, 2001).

47. Muslim b. al-Ḥajjāj, "Ṣaḥịh Muslim, kitāb al-'ilm, bāb raf" al- ilm wa-qabọihi wa-ẓuhūr al-jahl wa-'fitan fī ākhir al-zamān", Al-Islam.com, available online at http://hadith.al-islam.com/Page.asp x?pageid=192\&TOCID=1251\&BookID=25\&PID=4900 (accessed on 6 January 2011).

48. Sulaymān b. Ash 'ath, "Sunan Abī Dawud, kitāb al- 'ilm, bāb al-tawaqqu' fî̀ 'l-futyā", Al-Islam. com, available online at http://hadith.al-islam.com/Page.aspx?pageid=192\&TOCID=1391\&Boo $\mathrm{kID}=28 \& \mathrm{PID}=3174$ (accessed on 6 January 2011).

49. See Yūsuf al-Qaraḍāwī, Min hady al-islām: al-Fatāwā al-mu 'ạșirah, vols 1-2 (Al-Manșūrah [Egypt]: Dār Al-Wafā', 1994), also available online at http://www.qaradawi.net/site/topics/index. asp?cu_no $=2 \& \operatorname{lng}=0 \&$ template_id $=8 \&$ temp_type $=42 \&$ parent_id $=12$ (accessed on 29 November 2010).

50. See "MUIS Scholarship Award", available online at http://www.muis.gov.sg/cms/careers/ Scholarships.aspx?id=131\&terms $=$ scholarship $($ accessed on 11 November 2010).

51. See "History of LBKM", available online at http://www.bursary.org/container.html?history.html (accessed on 29 November 2010).

52. See LBKM, "Value of Bursaries", available online at http://www.bursary.org/container.html?bursary. html (accessed on 29 November 2010).

53. See the information on the Muhammadiyah Islamic College, available online at http://www. muhammadiyah.org.sg/index.php/about-us/index.php?option=com_content\&view=article\&id=1 $58 \&$ Itemid $=100$ (accessed on 29 November 2010). 
54. See the information on Institut Pengajian Islam Pergas, available online at http://www.pergas.org. sg/ipip.html (accessed on 29 November 2010).

55. See the information on the MUIS Academy, available online at http://www.pergas.org.sg/ipip.html (accessed on 29 November 2010).

56. "MUIS 3rd 3-Year Plan", NADi 2, no. 10 (July-September 2010), 18, available online at http:// www.muis.gov.sg/cms/uploadedFiles/MuisGovSG/Publications/Newsletters/Nadi\%2018(1).pdf (accessed on 17 January 2011).

57. Ibid.

58. Presentation of Third MUIS 3-Year Plan (3M3YP) at the MUIS Workplan Seminar 2010 on 10 April 2010.

59. Yūsuf al-Qaraḍāwī, "al-Fatwā bayn al-inḍibāṭ wa-'l-tasayyub”, available online at http:// www.qaradawi.net/site/topics/article.asp?cu_no $=2 \&$ item_no $=2924 \&$ version $=1 \&$ template $\mathrm{id}=24 \&$ parent_id=1 (accessed on 11 November 2010). 